\title{
Teacher Professionalism: subverting the society of control
}

\author{
PHIL WOOD
}

\begin{abstract}
The past 30 years have seen a series of major shifts in English education. Central to these changes has been the growth of data systems which now measure and control the work of teachers to a huge degree. This form of data-led surveillance was predicted in the work of Gilles Deleuze, a totalising process where data become more important than the individuals to which they relate. This article considers the ramifications of the development of a 'Society of Control' within education before arguing that teachers have begun to identify and occupy nomadic spaces capable of subverting State narratives and building new opportunities for professionalism. The development of teacher-led professional development and the use of social media have both led to new opportunities for professional dialogue and debate which are important in counteracting policy developments enacted by those outside the profession. Finally, it is suggested that responsibilities come with the creation of new spaces for professional dialogue and development if teachers are to move centre stage in the wider educational debate.
\end{abstract}

\section{Introduction}

Education has seen a major series of reforms within England and Wales since the mid-1980s which have had a fundamental impact on the work of teachers (Stevenson \& Wood, 2013). These changes have shifted the nature of education from one based on a public service ethos, teacher vocation, responsibility and public trust to a system based on the marketised principles of New Public Managerialism (Green, 2011). In this article I begin by exploring the rise of an education system driven by an imperative to collect data for quality assurance and management purposes, a development which I characterise as the consequence of the emergence of a Society of Control (Deleuze, 1990). While data-driven systems within education have considerable potential to restrict teacher autonomy, I argue that teachers have demonstrated their agency in a 
number of ways to create alternative professional and creative spaces. This acts as a mechanism for subverting State educational narratives concerning education, thereby reasserting to some degree a greater level of professionalism.

\section{Towards a Society of Control in Education}

In a short article written for L'Autre Journal (Deleuze, 1990) and presented in translated form in October (Deleuze, 1992), Gilles Deleuze outlines an explanation of the changing nature of society since the end of World War II, a thesis which builds on Foucault's (1991) earlier discussion of disciplinary societies. Disciplinary societies enclose time and space to organise the behaviour of individuals, exemplified by the bounded spaces of schools, hospitals or factories, each of which has a set of rules and traditions to which groups are expected to adhere; in each case the bounded nature of the space allows for the surveillance of groups, the most well-known example being Foucault's (1991) discussion of prisons in Discipline and Punish.

Deleuze (1992) argues that from the end of the Second World War onwards the enclosed spaces of the disciplinary society have been eroded and replaced by a system of flows, a system he calls the 'Society of Control'. This brings a shift in the way we understand the relationships between, and fabric of, social activities as he argues that society has moved away from definable, confined spaces and activities towards open, ubiquitous surveillance and control. As Deleuze (1992, p. 6) states,

the family, the school, the Army, the factory are no longer the distinct analogical spaces that converge towards an owner - state or private power - but coded figures - deformable and transformable of a single corporation that now has only stakeholders.

The disintegration of enclosed spaces has occurred at the same time as data flows have expanded, becoming an important element of most socio-economic activity. As more and more data are collected about individuals - for example, the capture of spending patterns or mobile phone tracking - value in postindustrial societies no longer exists within the physical person, but instead exists within their associated data flows, leading Deleuze to coin the term 'dividual'. Dividuals are characterised by their data rather than by their physical being. Taking up the theme of spending patterns, supermarkets have little interest in striking up a relationship with individuals themselves, merely reacting to their spending-pattern data to maximise sales and profit.

Factories are replaced by corporations which atomise labour, with declining union collectivism and more fluid working practices, encouraging individual competition within organisations, characterised as a healthy professional attribute, aiding the rise of individualism within the workplace. In education competitive individualism can be seen at school level through league tables, and more recently at individual level through the introduction of performance related pay (PRP). A small-scale study by Lundstrom (2012) 
interviewing 23 Swedish upper-secondary school teachers who were undergoing exposure to PRP as part of organisational restructuring showed that it led to a move from 'occupational' to 'organizational' professionalism (defined by Evetts, 2006). Occupational professionalism is characterised by discretionary decision-making in a climate of trust, based on a strong sense of social belonging and collective identity. In contrast, organizational professionalism is based on standardisation of work practices, hierarchies, target setting and performance review, all of which are more attuned to the work of the individual than to the work of the group.

Societies of Control also lead to a concentration of power towards those who 'own' the data. As highlighted above, once streams of data become established they are more important for an organisation than the corporeal body. Within the education system this transition has been obvious as data use has expanded and occupies an increasingly central position within the educative process. In moving to a performative system, Ball (2003, p. 220) states, '[i]t is the data-base, the appraisal meeting, the annual review, report writing, the regular publication of results and promotion applications, inspections and peer reviews that are the mechanics of performativity', and hence the core of the educational process.

Data and data management have become an imperative in a number of ways. Large-scale data systems now reside in schools, where they track and record all facets of each student from personal information, through achievements to behavioural records. This is a typical example of the way in which data and the systems on which they are built begin to characterise students and teachers as dividuals within an educational context. Students can become dehumanised, being merely streams of data, and in the worst cases educational decisions are increasingly based on the various elements of the data system rather than being arrived at through deeper engagement with real individuals; the data are used to decide what is most efficient.

Data streams have also begun to manage teachers. Through the use of examination results and achievement projections, data are rapidly becoming the core component in making judgements concerning the 'efficiency' and quality of teachers, supported by datasets detailing the 'quality' of learning through lesson observations. These datasets are heavily instrumental, with teacher standards mandated by the State characterising the officially sanctioned practices which are deemed acceptable. These datasets are then the basis for identifying the quality of schools through the publication of league tables (Herbert \& Thomas, 1998; Hoyle \& Robinson, 2003; Goldstein \& Leckie, 2008). League tables are argued to demonstrate overall quality of schools in terms of the education they provide, but they do not offer any attempt to locate schools in different contexts or circumstances (Levacic \& Woods, 2002; Woods $\&$ Levacic, 2002).

In England, the various datasets collated by schools and external educational organisations form the foundation for the audit trail of the Office for Standards in Education, Children's Services and Skills (Ofsted) (see e.g. 
Ofsted, 2014). Initial decisions concerning the quality of a school are made before an inspector ever spends time with the organisation, based wholly on the available datasets collated by the school and central government which relate to particular features of school activity. The visit is merely to verify the decisions already made. Some schools are very good at making 'a case' once the inspectors have arrived and can influence outcomes, but this still tends to be an argument based around datasets.

In many cases school leadership has become a form of perpetual Ofsted process. Many schools now carry out a constant 'inspection regime' throughout the year, the leadership team deciding on improvement priorities and assessing their own staff based on the same datasets that Ofsted will use to make its summative judgements (Hall \& Noyes, 2009; Wilkins \& Wood, 2009). Writing in 2004, as the Self-Evaluation Form (SEF) was in the process of being developed, MacBeath (2004, p. 8, quoted in Perryman, 2009, p. 628) stated:

Senior managers become resident inspectors, gathering and assembling data annually in order to complete the self-evaluation report, a story told in lifeless data and dry prose, concealing more than it reveals, tailored to what Ofsted wants to hear rather than what the school could, in less constrained circumstances, recount.

This is a sentiment that is echoed by Troman (1997, p. 363), reporting on a primary school case study: 'So complete is this relationship [self-management and school inspection] that the headteacher now refers to himself as the "resident inspector"'. Taken together, the current system operates by an acute form of dataveillance (Clarke, 1988) which extends temporally in all directions. Students and staff can be, and are, analysed both retrospectively and into the future, so that their complete record is available for scrutiny at any time. Target setting and self-evaluation of both groups created from datasets decide the trajectory for both student and teacher development.

Dividuation also extends into the professional development of teachers. This is an activity which is no longer optional for anyone wanting to develop their career; indeed, it can be argued that all too often professional development has become an externalised process of enforced change rather than an internal and professional process of growth. Development opportunities are often decided on the basis of data, and future improvements are targeted and determine whether efficient and sufficient progress has been acquired from the opportunities. Gleeson and Husbands (2003) show the importance of performance management at both an organisational and a personal level, while Green (2011, p. 48, quoting Reeves et al, 2002) states that performance management leads to "express performance targets in terms of measurable outputs, accountabilities and training/learning targets'.

The predominance of dataveillance is such that it plays a dominant role in controlling the social life of schools, and can be argued to have led to the creeping demise of professionalism and the subsequent proletarianisation of teachers. The idea of teacher proletarianisation is not new, and in England was 
first argued in the 1980s by Busswell (1980) and Ginsburg et al (1988, p. 332), as "administrative changes undermining teacher autonomy and authority were characterized in "technocratically rationalistic" terms (see Habermas, 1976) NOT IN REFS and linked with "democratic" electoral processes'. In revisiting the idea of proletarianisation, Ginsburg and Megahed (2009) characterise it as a fivefold process which (1) separates the conception and execution of work, (2) standardises and routinises work, (3) intensifies the demands put on workers, (4) reduces labour costs, and (5) fragments the labour process, including the introduction of unskilled or semi-skilled workers. Increasingly these features are apparent in the development of educational policy and management in England and Wales. The act of teaching and learning is strongly influenced by Ofsted structures; the apparent success or otherwise of students is characterised by the degree to which their assessment data relate to quantitative predictions, and in some schools even the content and approach to lessons might be decided by others, the teacher merely opening predetermined resources and following corporate lesson plans. At the same time, professional development foci are often likewise data driven, with teachers having little professional space for dialogue and debate that counter the State narrative.

The rise of the Society of Control within education highlights the increased centrality of data and the systems and processes that feed from them. The constant and nearly ubiquitous gaze of the results of this process are also clear to see. Teachers are increasingly restricted in their work, from the need to produce 'corporate' paperwork such as lesson plans which can be stored and scrutinised, through a number of different observational techniques, from learning walks to graded 'Mocksted' observations, to constant comparison against a set of teacher standards which further restrict the terms by which teachers are measured and which also act as another framework for data collection. The adoption of standards, the use of data analysis against sets of norms, and the understanding of teacher work as a 'measurable' process all suggest a competency-focused system. However, does such a system really uncover and understand the complexity of teacher work? Biesta (2014, pp. 122-123) states that

the idea of competence is beginning to monopolize the discourse about teaching and teacher education. It is, therefore, first of all the convergence towards one particular way of thinking and talking about teaching and teacher education that we should be worried about. After all, if there is no alternative discourse, if a particular idea is simply seen as 'common sense', then there is a risk that it stops people from thinking at all.

Data-driven systems are coordinated by the State machinery. Deleuze and Guattari (2004) describe the thought pattern of the State as stratified, operating in a pre-determined and 'rational' way, created through its own internalised logic, or, as Holland (2013, p. 45) describes it, as State thought: 
Its basis is the double-articulation of State power and universal reason, each of which enables and augments the other: the power of the State provides reason with a reality and a proper space of its own.

The reality which is created and imposed upon education is one which enshrines the reason of quantified accountability systems and policies which increase micromanagement of teacher work. Also, publications become increasingly self-referential as an internal rationale and reality is created which gives the State machinery its power. This is a form of 'striated' thought which follows pre-determined, narrow, prescribed channels. It is the thought of narrow guidelines and tick sheets, frameworks which have been created and sanctioned by the State as 'real' and 'rational'. However, this makes the State unwieldy, as those who work willingly under the apparatus can only accept its striated thought; to change reality, those of the State must wait for the hierarchy to sanction a new reality. This is the rationale of the Society of Control, where data are characterised as truth, and teacher work is increasingly bound to its production, embeddedness and scrutiny. This system can appear totalising, but alongside any State machinery can be found the beginnings of 'nomadism'.

\section{Teachers as Nomads}

Deleuze and Guattari (2004, p. 393) ask:

Problem I. Is there a way of warding off the formation of a State apparatus (or its equivalents in a group)?

They argue that one positive answer to this question can be found through the development of 'outside' or nomadic thought. Unlike State thought, nomadism inhabits a 'smooth space'. It is fluid and creative, and flows in whatever direction seems appropriate. I argue that this is the thought of the professional; again, Deleuze and Guattari (2004, p. 417) state:

[It is] an event-thought ... instead of a subject thought, a problemthought instead of an essence-thought or theorem: a thought that appeals to a people instead of taking itself for a government ministry.

Nomadic thought can be linked to the moment-to-moment professional thought of the teacher in the way they reflect on their work, in the ways in which they coordinate and make decisions constantly, every day. But it is also the understanding of pedagogy and education which is central to the professional becoming of teachers. While the State, through its control of the official structures of education, is able to create restrictive spaces, 'rational' spaces which are a reflection of official policies and 'truths', the work of teachers can create nomadic thought, smooth spaces through which their beliefs, ideas and innate professionalism are able to flow. 
Nomadic thought is the fluid realisation of teacher professionalism standing in opposition to the State machinery described in the previous section. But nomadism is a form of 'soft' power. The State machinery cannot be contested in a direct way, it is sedentary, large, powerful through the exertion of its own internalised rationality. Teachers cannot directly challenge the State system by refusing to collect data, or through an abandonment of State characterisation of 'outstanding' teaching. Instead, some teachers find alternative 'smooth' spaces of creativity and debate beyond the territory of the State through which they can reignite their professionalism and subvert the narrative of the State.

Creative spaces and activities can take a number of forms, particularly through the development of alternative approaches to teacher work and the use of social media. In the USA, Roy (2003, p. 13) studied an urban innovative school where the curriculum was enacted in ways different to the mainstream:

The Deleuzean notions I introduce help us to reopen petrified borders, as well as look for the possibilities of gaps and fissures, and in-between spaces, where learning takes place in unusual and discontinuous ways.

By working beyond the standard structures of the State, teachers have an alternative space to reassert their professionalism, to question and create new ways to understand and enact education. Some teachers use the remaining professional space they still retain within State structures to develop innovative pedagogic and curricular (e.g. Renshaw \& Wood, 2011) approaches, but this debate increasingly takes place beyond the restrictive bounds of the school.

There are a number of ways in which teachers create smooth spaces to reassert and develop their professional voice. Here, I highlight two examples first, the use of informal teacher dialogue through teacher-led meetings and conferences, and second, through the use of social media. In both cases these are counter to the increasingly individualistic gaze of dataveillance.

Teachmeets began in 2006 in Edinburgh, Scotland. They are teacher-led meetings where participants go to give short presentations about an element of their work in the classroom, typically talking for no more than 5 to 10 minutes. The exact format of each meeting is decided by those attending, and can include breakout discussions and resource demonstration/discussion. As described in the Times Educational Supplement (2011):

Five years ago this month, six teachers sat in an Edinburgh pub and discussed better forms of continuing professional development (CPD) than lengthy sessions from consultants and education experts.

They knew the real expertise was in the classrooms, where inventive, persistent teachers were trying thousands of new ideas that no one ever heard about. Some worked; some didn't. Getting that experience and discovery out of the classroom and into other teachers' heads became the goal. 
Important here is the fact that teachers are creating spaces to share ideas, some of which might be well developed, while others are evolving; it is an opportunity for teachers to discuss their work and develop creative practice in a safe and supportive space, a space where their professionalism is an innate element in the discussion and where summative judgement is replaced by debate. Such events are capable of evolving more collaboration and professional opportunities through the development of new networks.

More recently, groups of teachers have started to ask questions of research and evidence-based practice. This has led to the development of teacher-led research conferences, the first being researchED 2013, which attracted 500 participants, predominantly teachers, to meet and discuss research from an angle of 'what works'. It was planned as a point of crossover between teachers and researchers to develop stronger links between the two communities. It has also led to the organisation of a number of similar conferences as the interest in research develops.

These are two examples of teacher-led spaces of professional discussion and debate which allow teachers to express their professionalism and understanding of pedagogy unrestricted by State narratives; where the two narratives do cross, it is due to professional insight and understanding.

A longer perspective on professional engagement in fluid spaces can be found in the growth of social media in educational settings. Wood (2009) investigated the use of blogs by secondary geography teachers who used the medium to share pedagogic and curricular ideas. The use of the blogs was described by some research participants as a way of clearly differentiating their work in school from their wider interests in developing practical educational ideas as part of a geographical and pedagogic community beyond their immediate workplaces. Blogs have subsequently developed in a number of diverse ways beyond the sharing of resources and teaching ideas. Stitzlein and Quinn $(2012$, p. 191) investigated the role of blogs in teacher dissent. They argue:

As teachers navigate the limitations of their physical locality, including limitations on teachers' abilities to speak their views on school grounds, virtual spaces may offer persuasive spaces for engaging in larger discussions of educational policies with teachers beyond their school doors and with interested public viewers who otherwise would not hear teacher voices.

They argue that teachers demonstrate a lack of understanding of participatory democracy and that their voice tends to be confused, but at the same time offer some interesting alternatives to unpopular policies. Some bloggers take a personal approach, focusing on their own lives and thoughts as teachers and the associated complexities and frustrations which are at the centre of everyday experience; others discuss pedagogic issues through their blogs, while others focus on developing critiques of educational policy and practice. As such, there is a growing community of teachers who all have a very wide spectrum of 
perspectives on education and use these spaces as a way of engaging with others and reflecting on their professional and pedagogic work.

Twitter has also become increasingly popular as a discursive tool. Many teacher bloggers advertise their blog posts on Twitter, and then use it as a medium for discussion. Twitter is also used by some as a way of sharing links to useful resources or to educational news stories. At its best, social media can provide a fluid space for sharing and discussing ideas within a wider community of educational professionals; at its worst, it can become a divisive and negative space.

For those who do not have either the time or the inclination to develop their own blogs, there has been the development of shared spaces for debate and sharing. Pedagoo is a web-based teacher community which was set up by practitioners to share ideas and resources, as well as discuss educational issues. It has developed over time, leading to regular Pedagoo-hosted Teachmeets as well as a presence on Twitter. Another space, this time hosted by a national newspaper as opposed to teachers, is the Teacher Network, hosted by the Guardian newspaper. This is another space for sharing resources and ideas, but perhaps the most well-known element of this site is 'The Secret Teacher', 'anonymous blog post[s] about the trials, tribulations and frustrations of school life' (Guardian, 2014). This blog space gives teachers the opportunity to discuss the issues which are important to them and offer a series of personal perspectives on the realities of school life as felt by teachers.

All of the above are examples of how teachers act as nomads, finding creative and subversive spaces to reassert professionalism away from the direct gaze and power of the State. They are spaces of discussion and debate, of sharing and collaboration. The 'soft' power which resides within the nomadic spaces of social media and teacher-led professional development events has allowed many teachers to make new and fruitful contacts beyond their immediate workplaces. This in its own right can be an extremely liberating process as enthusiasm and confidence can develop from a coming together of like-minded professionals. Perhaps most importantly, these new professional spaces allow for increased levels of professional stimulation and debate unhindered by State-sanctioned frameworks and 'truths'.

While social media can provide a creative space for professional growth, processes of reterritorialisation within debates are always present. The lines of flight which occur as individuals and groups move into smooth spaces of creativity can be eroded and stifled by forces which attempt to reassert selfproclaimed norms, or which even use State narratives. More recently, the State itself has begun to inhabit the social media space, both directly and through the use of 'astroturfing' (Lee, 2010), a process where 'faceless' accounts are used to give the impression of grassroots political support to State narratives while attacking those who oppose. However, these accounts are actually run by political and associated bodies and are an attempt to embed State narratives in nomadic spaces. 


\section{Conclusion}

Ginsburg and Megahed (2009) argue that teachers began to go through the process of deprofessionalisation as bureaucratic and technical frameworks began to constrain their autonomy in the 1980s. The development of the State machinery has only continued to expand and intensify, as the need to collect evidence concerning all facets of school activity has developed into an internally rational system set by politicians and organisations such as Ofsted. Over the past 30 years the State has normalised a series of policy perspectives to such an extent that they are now seen as being 'truth' and imperative to educational and wider economic success. The consequence of the development of an educational Society of Control is to constantly restrict the work of teachers as the requirement to produce, analyse and react to ever more elaborate sets of data becomes central to the notion of what it means to be a teacher. With this has come the deprofessionalisation, and perhaps even the proletarianisation, of teacher work. However, increasingly teachers are not allowing themselves to be restricted in their work, and rather than accepting a debased form of labour within the State-sanctioned machinery, many are increasingly finding new ways to assert their professionalism beyond the formal spaces of the system. Important to this renaissance in teacher autonomy has been the nomadic space of social media which allows any within the profession to begin discussions and debates, and to share and develop resources, ideas and even campaigns against the State machinery itself. The role of teachers as nomads has brought an important new process of professionalisation back to education in England.

There are challenges in these new spaces, however. While nomadic spaces by definition are informal and fluid, those based on social media or in teacherled professional development are nevertheless public. For these new-found opportunities for professional dialogue to remain creative and to grow, it is imperative that teachers themselves take responsibility for the narratives they create. This requires respectful and professional dialogue which, while robust in the debate and defence of ideas, does not descend into personal attack and the formation of pseudo-State-machinic perspectives; these will only serve to dampen debate and professional growth and may, at worst, lead to the progressive encroachment of State dialogues into this space. Teachers have begun to reassert their place at the centre of educational dialogue through a dogged determination to retain and renew their professionalism. How they use this 'soft' power will determine the degree to which they are able not only to subvert the formal educational routines of the State but also to play a central role in redefining its very character. This is both a huge opportunity and a great responsibility.

\section{References}

Ball, S.J. (2003) The Teacher's Soul and the Terrors of Performativity, Journal of Education Policy, 18(2), 215-228. http://dx.doi.org/10.1080/0268093022000043065 
Biesta, G.J.J. (2014) The Beautiful Risk of Education. Boulder, CO: Paradigm.

Busswell, C. (1980) Pedagogic Change and Social Change, British Journal of Sociology of Education, 1(3), 293-306. http://dx.doi.org/10.1080/0142569800010304

Clarke, R. (1988) Information Technology and Dataveillence, Communications of the ACM, 31(5), 498-512. http://dx.doi.org/10.1145/42411.42413

Deleuze G (1990) Post-scriptum sur les sociétés de controle, L'Autre Journal, 1.

Deleuze, G. (1992) Postscript on the Societies of Control, October, 59 (Winter), 3-7.

Deleuze, G. \& Guattari, F. (2004) A Thousand Plateaus. London: Continuum.

Evetts, J. (2006) Short Note: the sociology of professional groups, Current Sociology, 54(1), 133-143. http://dx.doi.org/10.1177/0011392106057161

Foucault, M. (1991) Discipline and Punish: the birth of the prison. London: Penguin.

Ginsburg, M. \& Megahed, N.W. (2009) Comparative Perspectives on Teachers, Teaching and Professionalism, in L.J. Saha \& A.G. Dworkin (series eds) International Handbook of Research on Teachers and Teaching, vol. 21, Springer International Handbooks of Education. Norwell, MA: Springer.

Ginsburg, M., Wallace, G. \& Miller, H. (1988) Teachers, Economy, and the State: an English example, Teaching and Teacher Education, 4(4), 317-337. http://dx.doi.org/10.1016/0742-051X(88)90031-5

Gleeson, D. \& Husbands, C. (2003) Modernizing Schooling through Performance Management: a critical appraisal, Journal of Education Policy, 18(5), 499-511. http://dx.doi.org/10.1080/0268093032000124866

Goldstein, H. \& Leckie, G. (2008) School League Tables: what can they really tell us? Significance, June, 67-69.

Green, J. (2011) Education, Professionalism and the Quest for Accountability. New York: Routledge.

Guardian (2014) The Secret Teacher. http://www.theguardian.com/profile/The-Secretteacher

Habermas, J. (1976) Legitimation Crisis. London: Heinemann Educational Books.

Hall, C. \& Noyes, A. (2009) New Regimes of Truth: the impact of performative school Self-evaluation systems on teachers' professional identities, Teaching and Teacher Education, 25, 850-856. http://dx.doi.org/10.1016/j.tate.2009.01.008

Herbert, D.T. \& Thomas, C.J. (1998) School Performance, League Tables and Social Geography, Applied Geography, 18(3), 199-223. http://dx.doi.org/10.1016/S0143-6228(98)00015-0

Holland, E.W. (2013) Deleuze and Guattari's A Thousand Plateaus. London: Bloomsbury.

Hoyle, R.B. \& Robinson, J.C. (2003) League Tables and School Effectiveness: a mathematical model, Proceedings of the Royal Society of London B, 270, 113-119. http://dx.doi.org/10.1098/rspb.2002.2223

Lee, C.W. (2010) The Roots of Astroturfing, Contexts, Winter, 73-74.

Levacic, R. \& Woods, P.A. (2002) Raising School Performance in League Tables (Part 1): disentangling the effects of social disadvantage, British Educational Research Journal, 28(2), 207-226. http://dx.doi.org/10.1080/01411920120122158

Lundstrom, U. (2012) Teachers' Perceptions of Individual Performance-related Pay in Practice: a picture of a counterproductive pay system, Educational Management 
Administration and Leadership, 40(3), 376-391.

http://dx.doi.org/10.1177/1741143212436954

MacBeath, J. (2004) Inside job, Guardian, 20 April.

Office for Standards in Education (Ofsted) (2014) School Data Dashboard Guidance. http://dashboard.ofsted.gov.uk/sdd_guidance.pdf

Perryman, J. (2009) Inspection and the Fabrication of Professional and Performative Processes, Journal of Education Policy, 24(5), 611-631. http://dx.doi.org/10.1080/02680930903125129

Reeves, J., Forde, C., O’Brien, J., Smith, P. \& Tomlinson, H. (2002) Performance Management in Education: improving practice. London: Paul Chapman and Sage.

Renshaw, S. \& Wood, P. (2011) Holistic Understanding in Geography Education (HUGE): an alternative approach to curriculum development and learning at Key Stage 3, Curriculum Journal, 22(3), 365-379. http://dx.doi.org/10.1080/09585176.2011.601656

Roy, K. (2003) Teachers in Nomadic Spaces: Deleuze and curriculum. New York: Peter Lang.

Stevenson, H. \& Wood, P. (2013) Markets, Managerialism and Teachers' Work: the invisible hand of high stakes testing in England, International Education Journal: comparative perspectives, 12(1), 42-61.

Stitzlein, S.M. \& Quinn, S. (2012) What Can We Learn from Teacher Dissent Online? Educational Forum, 76(2), 190-200. http://dx.doi.org/10.1080/00131725.2011.653870

Times Education Supplement (2011) Dodging Camels at the 'Unconference'. http://www.tes.co.uk/article.aspx?storycode $=6086014$

Troman, G. (1997) Self-management and School Inspection: complementary forms of surveillance and control in the primary school, Oxford Review of Education, 23(3), 345-364. http://dx.doi.org/10.1080/0305498970230306

Wilkins, C. \& Wood, P. (2009) ITE in the Panopticon, Journal of Education for Teaching: international research and pedagogy, 35(3), 283-297.

Wood, P. (2009) Advances in E-learning: the case of blogging in UK school geography, Research in Geographic Education, 11(2), 28-46.

Woods, P.A. \& Levacic, R. (2002) Raising School Performance in the League Tables (Part 2): barriers to responsiveness in three disadvantaged schools, British Educational Research Journal, 28(2), 227-247. http://dx.doi.org/10.1080/01411920120122167

PHIL WOOD is a senior lecturer at the School of Education, University of Leicester, where he has an interest in complexity theory and pedagogic innovation. Correspondence: pbw2@1e.ac.uk 